\title{
Species identification of ruminant milk by genotyping of the K-casein gene
}

\author{
R. R. Vafin, ${ }^{1} \odot$ A. G. Galstyan, ${ }^{2} \odot$ S. V. Tyulkin, ${ }^{1} \odot$ Kh. Kh. Gilmanov, ${ }^{1} \oplus$ E. A. ${ }^{\circ}$ urova, ${ }^{2}{ }^{\oplus}$ V. K. Semipyatniy, ${ }^{2 *} \odot$ \\ and A. V. Bigaeva ${ }^{2}$ (i) \\ ${ }^{1}$ V.M. Gorbatov Federal Research Center for Food Systems of Russian Academy of Sciences, 109316, Moscow, Russia \\ ${ }^{2}$ All-Russian Scientific Research Institute of the Dairy Industry, 115093, Moscow, Russia
}

\begin{abstract}
The development of molecular genetic and bioinformatic systems for identifying the species of milk and the raw material composition of dairy products is of great scientific and practical importance with the purpose of introducing developments in the system for controlling the turnover of falsified products. The aim of the research is to develop a method of PCR-RFLP analysis for species identification of milk and dairy products from agricultural ruminant animals by the k-casein gene (CSN3) with the possibility of qualitative and relative quantitative assessment of species-specific DNA of the tested biomaterial. The objects of research were samples of raw milk and milk powder, pasteurized cream, and hard and semi-hard cheeses. The developed method of species identification of milk and dairy products includes sample preparation of the studied samples, nucleic acid extraction, combined PCR-RFLP technique, detection of obtained results by the method of horizontal electrophoresis in agarose gel and their analysis, including using the developed mathematical algorithms and software. The synergistic effect established in combined operation of 2 restriction enzymes ensured their application in a mix with increased performance in an ergonomic way in the context of DNA authentication of cow, goat, and sheep milk and dairy products based on them. The specificity and sensitivity of the proposed method is potentially suitable for implementing the development of a system to control the turnover of falsified and counterfeit goods.
\end{abstract}

Key words: authentication, ruminants, DNA, $\kappa$-casein, PCR

\section{INTRODUCTION}

In the modern food system one of the most important aspects is the problem of identification of food raw

Received November 19, 2020.

Accepted September 29, 2021.

*Corresponding author: semipyatniy@gmail.com material and food products. To date, this is closely related to the country's food security, including in terms of controlling the turnover of low-quality, counterfeit, and falsified products (Creydt and Fischer, 2020). Among many analytical methods, we should single out those that contribute to the authentication of food raw material and food products by biological and geographical affiliation (Poonia et al., 2017; Abbas et al., 2018; Böhme et al., 2019a). In this perspective, it is most appropriate to use analysis methods based on the principles of measurement of high-performance DNA technologies (Levin et al., 2018; Böhme et al., 2019b; Kang, 2019). DNA-based authentication of foods and raw materials is the process of confirming their authenticity, taking into account the individual characteristics of the hereditary material of the studied components of biological objects (Lo and Shaw, 2018; Oganesyants et al., 2018; Habza-Kowalska et al., 2019).

Regarding the DNA authentication of milk and dairy products, the first step is the identification of the type of milk and the raw material composition of dairy products, sourced from the main set of dairy animal species, which together account for $99 \%$ of world milk production. The procedure of DNA authentication assumes the possibility of detecting partial substitution of the declared type of milk by molecular genetic analysis of unique gene loci (Agrimonti and Marmiroli, 2018; Kalogianni, 2018; Agrimonti et al., 2019). The most common method for species identification in milk and dairy products is PCR followed by electrophoresis and hybridization-fluorescence detection of amplification products (Choopan et al., 2017; Di Domenico et al., 2017; Cosenza et al., 2019; Tsakali et al., 2019; Di Febo et al., 2020; Tsirigoti et al., 2020). Additional authentication approaches based on the length polymorphism of restriction fragments of amplified DNA (PCR-RFLP) have also found their application along with methods of hybridization, sequence, and biosensor analysis of the corresponding nucleotide sequences of mitochondrial and nuclear genes (Abdel-Rahman and Ahmed, 2007; Tillmar et al., 2013; Ripp et al., 2014; Abdelfatah et al., 2015; Beltramo et al., 2017; Kounelli and Kalogianni, 
2017; Ewida and Abd El-Magiud, 2018: Ribani et al., 2018; El Sheikha, 2019; Bougadi and Kalogianni, 2020).

The technological accessibility and simplicity of the PCR-RFLP, as well as its analytical characteristics (sensitivity, specificity, and reproducibility), ensure the correct interpretation of the results. In general, this informative authentication method is diagnostically significant and popular, despite the relatively long procedure for endonuclease cleavage of the synthesized PCR product (Hashim and Al-Shuhaib, 2019). Among the many identification molecular markers of nuclear DNA, the genes of milk proteins linked to economically valuable traits of animals deserve attention (Tyulkin, 2018). In particular, it is the $\kappa$-casein gene (CSN3), whose intra- and interspecies genetic polymorphism is the most studied and is widely represented in the form of deposited nucleotide sequences in bioinformatics databases.

In view of the above, research on improving molecular genetic and bioinformatic systems for identifying species affiliation of milk and dairy products is of great scientific and practical importance with the prospect of introducing developments in the system for controlling the turnover of falsified products. In particular, the adulteration of milk and dairy products is one of the important issues in food safety (Deng et al., 2020). The purpose of this work is to develop a technique for PCR-RFLP analysis for species identification in milk and dairy products from agricultural ruminant animals by the $\kappa$-casein gene with the possibility of qualitative and relative quantitative assessment of species-specific DNA of the tested biomaterial by specialized software.

\section{MATERIALS AND METHODS}

The work was carried out on the basis of the V.M. Gorbatov Federal Research Center for Food Systems of Russian Academy of Sciences and the All-Russian Research Institute of the Dairy Industry. The materials under study were samples of raw cow and sheep milk, whole goat milk powder, cow milk pasteurized cream with a 50\% mass fraction of fat, as well as cheeses from cow (semi-hard Gouda cheese), goat (semi-hard Manchego cheese), and sheep (hard Moliterno cheese with truffle) milk. The developed technique for species identification in milk and dairy products from agricultural ruminant animals by the $\kappa$-casein gene includes sample preparation of the studied samples, isolation of nucleic acids, combined PCR and RFLP (PCR-RFLP), detection of the results obtained by horizontal electrophoresis in agarose gel and their analysis, including using the created mathematical algorithms and software (https:/ /tinyurl.com/kappacasein).
Sampling of raw milk and cream was performed by centrifugation of the liquids selected and introduced into Eppendorf test tubes in volumes of $1.5 \mathrm{~mL}$ at 10,000 $\times g$ for $15 \mathrm{~min}$ at room temperature (CM-50, Elmi), with further removal of the supernatant using an aspirator with a flask trap (FTA-1, Biosan). Samples of milk powder and cheese were placed in Eppendorf-type test tubes in the form of a 50-mg sample for further DNA extraction. Nucleic acids were isolated from the samples using a set with reagents for DNA extraction from biological material DNA-sorb-S-M (AmpliSens) according to the manufacturer's instructions on the kit.

Reaction mixtures for PCR were prepared based on the calculation for 1 reaction in a volume of $50 \mu \mathrm{L}$ with the content of $32.5 \mu \mathrm{L}$ of deionized water, $5 \mu \mathrm{L}$ of $2.5 \mathrm{mM}$ dNTPs, $5 \mu \mathrm{L}$ of $10 \times$ buffer components, 0.5 $\mu \mathrm{L}(5 \mathrm{U} / \mu \mathrm{L})$ of Taq DNA polymerase (SibEnzyme), $1 \mu \mathrm{L}$ of $0.5 \mu \mathrm{M}$ primers JK5: 5'-ATCATTTATGGCCATTCCACCAAAG- $3^{\prime}$, and $1 \mu \mathrm{L}$ of $0.5 \mu M$ primers JK3: 5'-GCCCATTTCGCCTTCTCTGTAACAGA-3' (Medrano and Cordova, 1990), followed by adding 5 $\mu \mathrm{L}$ (not less than $5 \mathrm{ng} / \mu \mathrm{L}$ ) of the DNA sample under the mineral oil layer. The PCR was carried out on a DNA amplifier Tertsik (DNA-Technology) using the following thermal cycling program: $\times 1: 94^{\circ} \mathrm{C}$ for $4 \mathrm{~min}$, $\times 30-40: 94^{\circ} \mathrm{C}$ for $10 \mathrm{~s}, 63^{\circ} \mathrm{C}$ for $10 \mathrm{~s}, 72^{\circ} \mathrm{C}$ for $10 \mathrm{~s}$, and $\times 1$ : $72^{\circ} \mathrm{C}$ for $7 \mathrm{~min}$.

Reaction mixtures for RFLP analysis were prepared based on the calculation for 1 reaction in a volume of $20 \mu \mathrm{L}$ containing the calculated amounts of deionized water, corresponding buffer component systems, and restriction enzymes $X b a \mathrm{I}$ (4 units), PsiI (2 units), and $R s a \mathrm{I}$ (4 units) produced by SibEnzyme (Russia), both separately and in a mix $(X b a \mathrm{I}+$ PsiI $)$, followed by $10-\mu \mathrm{L}$ PCR samples under a layer of mineral oil and incubation at $37^{\circ} \mathrm{C}$ overnight.

Electrophoretic detection of PCR products and RFLP fragments was performed in a $2 \%$ agarose gel on a $1 \times$ Tris-borate-EDTA (TBE) buffer with ethidium bromide $(0.3 \mu \mathrm{g} / \mathrm{mL})$, using a chamber for horizontal electrophoresis SE2 (Helicon) with a power supply Elf4 (DNA-Technology) with a programmed mode (150 $\mathrm{V}, 150 \mathrm{~mA}, 50 \mathrm{~W}, 30 \mathrm{~min})$. Subsequent visualization of the obtained results was carried out in a UV transilluminator of the gel documentation system Gel Doc XR+ with the support of the Image Lab software (Bio-Rad).

In silico simulation of PCR-RFLP profiles was done using NEBcutter v.2.0 (http://nc2.neb.com/ NEBcutter2/). Alignment of partial nucleotide sequences of the CSN3 gene locus of agricultural ruminant animals with flanking by primers JK5 and JK3 was done by BLAST (https://blast.ncbi.nlm.nih.gov/ Blast.cgi) and ClustalW (https://www.genome.jp/tools 
-bin/clustalw). We also determined the ratio of the relative shares of the CSN3 gene of agricultural ruminant animals in milk sample using our software, which is publicly available at https://tinyurl.com/kappacasein.

\section{RESULTS AND DISCUSSION}

Species identification in milk and raw material composition of dairy products was performed based on the developed PCR-RFLP technique for the analyzed locus of the $\kappa$-casein gene of agricultural ruminant animals.

The calculated data for verification of the proposed PCR-RFLP technique were obtained based on the analysis of alignment and restriction mapping of the reference nucleotide sequences CSN3 Bos taurus, Bubalus bubalis, Capra hircus, and Ovis aries amplified using primers JK5 and JK3 (Figure 1). Enzyme selection (XbaI, PsiI, RsaI) for RFLP analysis was carried out based on the presence of diagnostically important restriction enzyme sites in the nucleotide sequences of the DNA of the analyzed gene locus.

The result of alignment and restriction mapping indicated, in particular, the possible generation of $X b a I-R F L P$ profiles, which theoretically provide differentiation of Bos taurus and Bubalus bubalis from Capra hircus and Ovis aries. At the same time, the Psi-RFLP profile of Ovis aries had the potential to identify sheep milk and dairy products based on it, and the $R s a \mathrm{I}$ RFLP profile of Bubalus bubalis milk and products of its processing (Figure 1). Thus, the interpretation of the generated RFLP profiles for 3 restriction endonucleases used both separately and in a mix $(X b a \mathrm{I}+$ $P s i \mathrm{I})$ allows for the species identification in milk and dairy products with the possibility of detecting partial substitution of the declared type of raw material, based on the information presented in Table 1.

When testing the developed technique for performing PCR-RFLP on a sample of raw cow milk, we obtained a technical result that overall corresponds to the calculated data (Figure 2). The amplified PCR product of the CSN3 gene locus of the Bos taurus with a length of 350 bp was cut by $2(X b a \mathrm{I}$ and $R s a \mathrm{I})$ of the 3 restriction endonucleases used, which generated a species-specific RFLP profile, DNA-specific, extracted from somatic cells of cow milk (Figure 2). In addition, we found that the performance of $\mathrm{X} b a \mathrm{I}$ restriction enzyme together with buffer $\mathrm{O}$ and BSA was significantly lower (Figure 2, track 2) than with buffer B in the mix with PsiI restriction enzyme (Figure 2, track 5). Therefore, we decided to use buffer B for all 3 restriction enzymes. We also considered that $R s a \mathrm{I}$, which effectively cut the amplicon into fragments of 262 and $88 \mathrm{bp}$, is equipped with this buffer along with the PsiI restriction endonuclease. When testing the proposed PCR-RFLP technique on a sample of goat dry milk, a practical result was also obtained that is identical to the theoretical calculations (Figure 3). The RFLP profile of DNA Capra hircus is species specific in the combined interpretation of data for 3 restriction enzymes, of which only $R s a \mathrm{I}$ cuts the amplified PCR product with a length of $356 \mathrm{bp}$ into fragments with a size of 262 and $87 \mathrm{bp}$ (Figure 3). At the same time, the procedure of endonuclease cleavage by $X b a \mathrm{I}$ and $P s t \mathrm{I}$ restriction enzymes in the mix, which does not lead to DNA cutting due to the absence of corresponding restriction sites in the analyzed CSN3 gene locus Capra hircus, allows identifying goat milk by a single RFLP analysis, differentiating it from cow, buffalo, and sheep milk (Figure 1, Figure 3).

Taking into account that setting PCR in the thermal cycling mode at 40 cycles led to a small background amplification, which did not significantly affect the analysis of data, in subsequent sets with DNA samples extracted from dry and raw milk, the number of cycles was reduced to 30 , obtaining completely reproducible results.

Testing of the used PCR-RFLP technique on a sample of sheep raw milk revealed a diagnostically significant pattern (Figure 4). In particular, we found that Psi restriction enzyme is more efficient in the mix with $X b a \mathrm{I}$ restriction endonuclase (Figure 4, track 5 ) than in its individual application (Figure 4, track 3). This fact, together with another previously stated observation, indicates the formation of a synergistic effect when the 2 listed enzymes work together. Several generated minor RFLP fragments of size $66 \mathrm{bp}$ (Figure 4, track 3) and $87 \mathrm{bp}$ (Figure 4, track 4) were not visible in the setting of PCR at 30 cycles.

In general, RFLP profile of DNA Ovis aries is species specific, both for the combined interpretation of data for 3 restriction endonucleases and for 2 restriction endonucleases $(X b a \mathrm{I}+P s i \mathrm{I})$ in a mix with higher performance (Figure 4).

Another clear result of PCR-RFLP analysis of the species identification in individual milk samples using the CSN3 gene is shown in the electropherogram of Figure 5. When interpreting the generated RFLP profiles for 2 restriction enzymes $(X b a \mathrm{I}+P s i \mathrm{I})$ in the mix, it is sufficient to focus only on the identificationsignificant major RFLP fragments (223 bp for DNA Bos taurus, 356 bp for Capra hircus, and 285 bp for Ovis aries), without focusing on minor fragments (127 bp for Bos taurus, $66 \mathrm{bp}$ for Ovis aries) that are weakly or completely indistinguishable in the PCR setting at 30 cycles (Figure 5).

The calculated coefficients obtained by arithmetic operation (division) of the numerical values of the lengths of PCR products (divisible) and RFLP fragments (divisor) are presented in Table 2. In this case, 


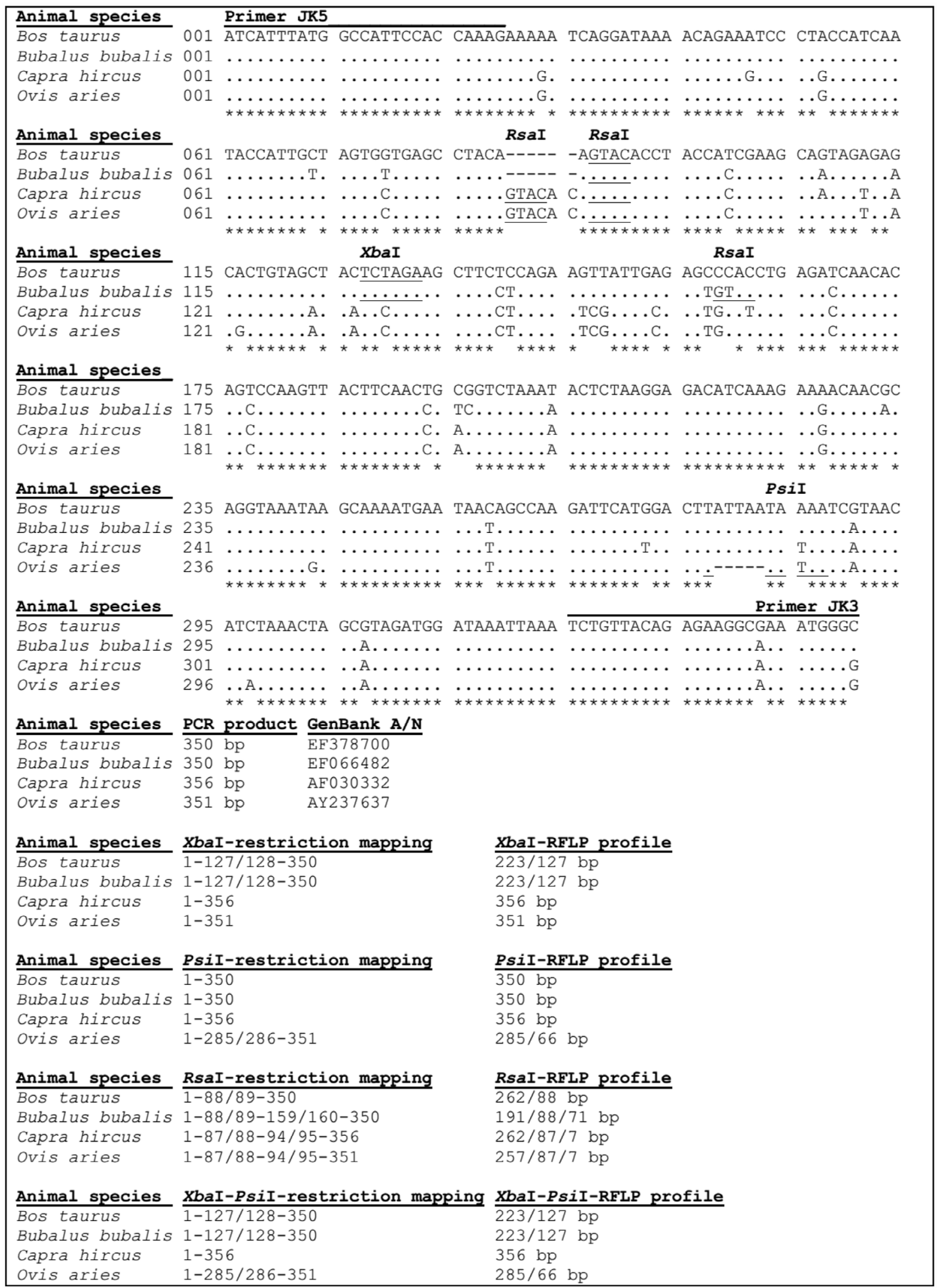

Figure 1. Result of alignment and restriction mapping of reference nucleotide sequences of CSN3 gene locus of the agricultural ruminant animals amplified with JK5 and JK3 primers. · denotes identical nucleotide sequences in DNA. * denotes conserved nucleotide sequences in DNA. 
Table 1. Restriction fragment length polymorphism (RFLP) profiles (fragments in bp) of the CSN3 gene locus of the agricultural ruminant animals

\begin{tabular}{|c|c|c|c|c|}
\hline Animal species ${ }^{1}$ & \multicolumn{4}{|c|}{ Restriction enzyme } \\
\hline $\mathrm{BB}$ & $223 / 127$ & 350 & $191 / 88 / 71$ & $223 / 127$ \\
\hline $\mathrm{CH}$ & 356 & 356 & $262 / 87 / 7$ & 356 \\
\hline $\mathrm{OA}$ & 351 & $285 / 66$ & $257 / 87 / 7$ & $285 / 66$ \\
\hline $\mathrm{BT}+\mathrm{BB}$ & $223 / 127$ & 350 & $262 / 191 / 88 / 71$ & $223 / 127$ \\
\hline $\mathrm{BB}+\mathrm{CH}$ & $356 / 223 / 127$ & $356 / 350$ & $262 / 191 / 88 / 87 / 71 / 7$ & $356 / 223 / 127$ \\
\hline $\mathrm{BB}+\mathrm{OA}$ & $351 / 223 / 127$ & $350 / 285 / 66$ & $257 / 191 / 88 / 87 / 71 / 7$ & $285 / 223 / 127 / 66$ \\
\hline $\mathrm{CH}+\mathrm{OA}$ & $356 / 351$ & $356 / 285 / 66$ & $262 / 257 / 87 / 7$ & $356 / 285 / 66$ \\
\hline $\mathrm{BT}+\mathrm{BB}+\mathrm{CH}$ & $356 / 223 / 127$ & $356 / 350$ & $262 / 191 / 88 / 87 / 71 / 7$ & $356 / 223 / 127$ \\
\hline $\mathrm{BT}+\mathrm{BB}+\mathrm{OA}$ & $351 / 223 / 127$ & $350 / 285 / 66$ & $262 / 257 / 191 / 88 / 87 / 7$ & $285 / 223 / 127 / 66$ \\
\hline $\mathrm{BT}+\mathrm{CH}+\mathrm{OA}$ & $356 / 351 / 223 / 127$ & $356 / 350 / 285 / 66$ & $262 / 257 / 88 / 87 / 7$ & $356 / 285 / 223 / 127 / 66$ \\
\hline $\mathrm{BB}+\mathrm{CH}+\mathrm{OA}$ & $356 / 351 / 223 / 127$ & $356 / 350 / 285 / 66$ & $262 / 257 / 191 / 88 / 87 / 7$ & $356 / 285 / 223 / 127 / 66$ \\
\hline
\end{tabular}

${ }^{1} \mathrm{BT}=$ Bos taurus $; \mathrm{BB}=$ Bubalus bubalis; $\mathrm{CH}=$ Capra hircus $; \mathrm{OA}=$ Ovis aries.

the calculated coefficients of identifiable major RFLP fragments (1 for XbaI-PsiI-RFLP-fragment with a length of $356 \mathrm{bp}$ for Capra hircus DNA, 1.23-285 bp for Ovis aries, and 1.57-223 bp for Bos taurus) can be used to determine the ratio of relative shares of the $\kappa$-casein gene in agricultural ruminant animals in the process of species identification in milk and dairy products. The potential of PCR-RFLP identification of species affiliation of mixed milk samples is clearly demonstrated in the electropherogram of Figure 6. We generated data for determining the ratio of the relative shares of the CSN3 gene of agricultural ruminant animals in the studied biomaterials. Data obtained during the subse-

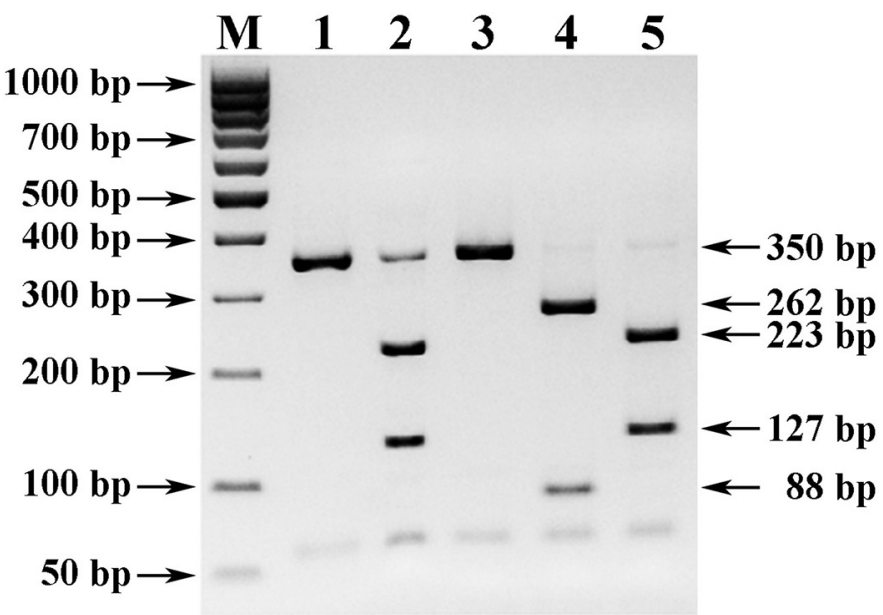

Figure 2. Electropherogram of the result of PCR-RFLP analysis of the species identification in cow milk by the CSN3 gene. $\mathrm{M}=\mathrm{PCR}$ marker (SibEnzyme); $1=$ PCR product $(350 \mathrm{bp}) ; 2=X b a \mathrm{I}-\mathrm{RFLP}$ fragment $(223 / 127 \mathrm{bp}) ; 3=$ Psi $\mathrm{I}-\mathrm{RFLP}$ fragment $(350 \mathrm{bp}) ; 4=$ RsaIRFLP fragment (262/88 bp); $5=$ XbaI-PsiI-RFLP fragment $(223 / 127$ $\mathrm{bp})$.

Journal of Dairy Science Vol. 105 No. 2, 2022 quent statistical analysis of the results of PCR-RFLP identification of the species in mixed milk samples are presented in Table 3.

Figure 7 shows the interface of the "Determining the ratio of relative shares of $\kappa$-casein of agricultural ruminant animals in tested samples of milk and dairy products" program, which streamlines the process of CSN3 gene share calculation. It should be noted that determining the relative proportions of CSN3 gene in agricultural ruminant animals is equivalent to determining the percentage of the number of Bos taurus, Capra hircus, and Ovis aries genomes in mixed milk samples (Table 3, Figure 7). Obtained results indicate that it is possible to detect partial or complete substitution of

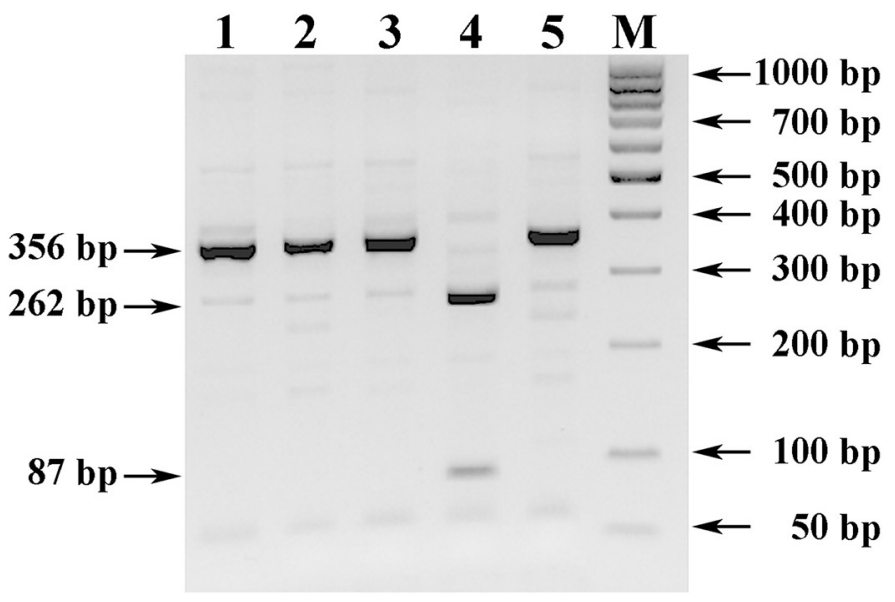

Figure 3. Electropherogram of the result of PCR-RFLP analysis of the species identification in goat milk by the CSN3 gene. $1=\mathrm{PCR}$ product $(356 \mathrm{bp}) ; 2=X b a \mathrm{I}-\mathrm{RFLP}$ fragment $(356 \mathrm{bp}) ; 3=$ PsiI-RFLP fragment (356 bp); $4=R s a \mathrm{I}-\mathrm{RFLP}$ fragment $(262 / 87 \mathrm{bp}) ; 5=X b a \mathrm{I}-$ Psi-RFLP fragment (356 bp); M = PCR marker (SibEnzyme). 


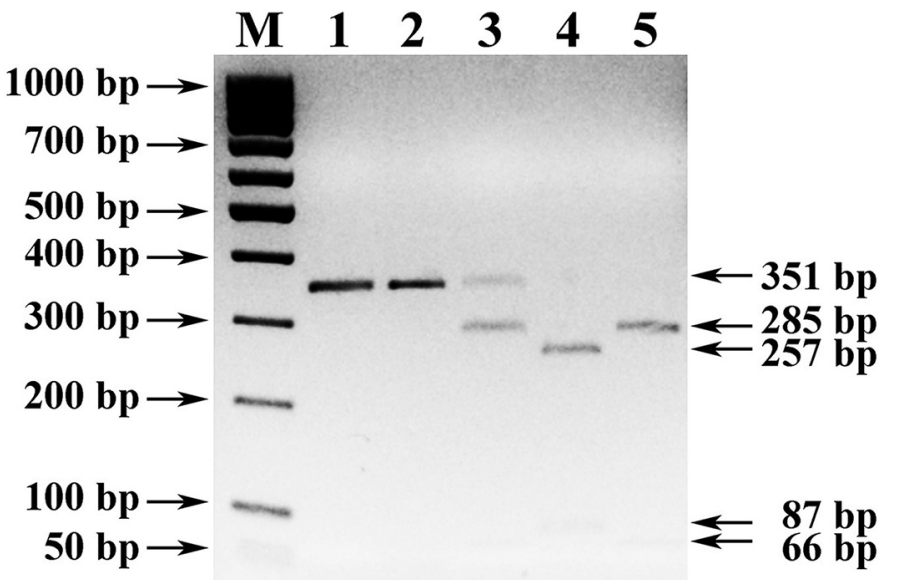

Figure 4. Electropherogram of the result of PCR-RFLP analysis of the species identification in sheep milk by the CSN3 gene. $\mathrm{M}=$ PCR marker (SibEnzyme); $1=$ PCR product (351 bp) $2=X b a \mathrm{I}-$ RFLP fragment (351 bp); $3=$ PsiI-RFLP fragment (285/66 bp); 4 $=R s a \mathrm{I}-\mathrm{RFLP}$ fragment $(257 / 87 \mathrm{bp}) ; 5=X b a \mathrm{I}-P s i \mathrm{I}-\mathrm{RFLP}$ fragment (285/66 bp).

the declared milk type using the PCR-RFLP analysis (Figure 6) following the software analysis. This allows for quality control (conformity assessment) of products including those made from mixed sources of dairy raw material from different types of agricultural ruminant animals. The PCR-RFLP analysis of species identification of cheeses by CSN3 gene, the visual result of which is shown in the electropherogram of Figure 8, confirms the applicability of the developed technique in relation to the molecular genetic testing of dairy products.

Insignificant background amplification in PCR samples with DNA samples extracted from goat and sheep

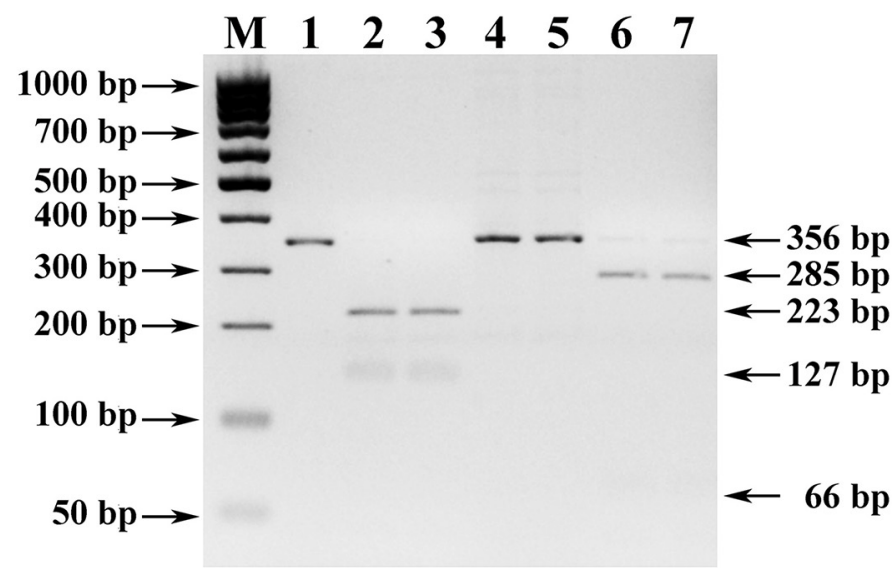

Figure 5. Electropherogram of the result of PCR-RFLP analysis of the species identification in individual milk samples by the CSN 3 gene. $\mathrm{M}=\mathrm{PCR}$ marker (SibEnzyme); 1 = PCR product Bos taurus $(350$ bp); $2-7=$ XbaI-PsiI-RFLP fragments: $2-3$, Bos taurus (223/127 bp); 4-5, Capra hircus (356 bp); 6-7, Ovis aries (285/66 bp). cheese, observed when PCR was set up in the thermal cycling mode at 40 cycles (Figure 8), disappeared in the subsequent setting at 35 cycles, which also ensured the high-quality operation of $X b a \mathrm{I}$ and $P s i \mathrm{I}$ restriction enzymes in the mix, generating species-specific RFLP fragments. Comparable results were also obtained by DNA testing of cream pasteurized from cow milk with a mass fraction of fat of $50 \%$ for identification of the species in the raw material composition by the proposed PCR-RFLP analysis technique in the thermal cycling mode at 40 cycles.

Isolation of DNA from the studied biomaterial is a key procedure, the quality of which determines the effectiveness of the subsequent stages of genodiagnostics. The DNA-sorb-S-M kit successfully used in this work is designed, according to the instructions, for extracting nucleic acids from biological material from animals (tissue material) and food, biological additives, animal feed, or plant raw material for further research by PCR method. At the same time, other equally effective methods for extracting genomic (Liu et al., 2014) and mitochondrial (Liao et al., 2017a) DNA in samples of milk and dairy products, including milk powder (Xu and Ma, 2012; Liao et al., 2017b), are known to reflect aggregate information about the approaches used in the 2 review publications (Agrimonti and Marmiroli, 2018; Kalogianni, 2018).

The target of JK5 and JK3 primers used in PCR is the nuclear DNA of the $\kappa$-casein gene locus in agricultural ruminant animals (Bos taurus, Bubalus bubalis, Capra hircus, and Ovis aries). The given set of oligonucleotides, originally designed for cattle genotyping by RFLP analysis allele-specific restriction enzyme HinfI (Medrano and Cordova, 1990), has found a new field of application with selected species-specific restriction endonucleases $X b a \mathrm{I}, P s i \mathrm{I}$, and RsaI. Among milk protein genes, in addition to the $\kappa$-casein gene (Reale et al., 2008 ), the potential of $\beta$-casein (Otaviano et al., 2008) and $\alpha$-LA (Cosenza et al., 2019) as DNA markers of the species belonging to milk and dairy products has also been studied, with the vast majority of published case studies and research aimed at molecular genetic analy-

Table 2. Estimated coefficients of the generated XbaI-PsiI-RFLP fragments

\begin{tabular}{lccc}
\hline $\begin{array}{l}\text { Animal } \\
\text { species }\end{array}$ & $\begin{array}{c}\text { PCR } \\
\text { product, bp }\end{array}$ & $\begin{array}{c}\text { XbaI-PsiI-RFLP } \\
\text { fragment, bp }\end{array}$ & $\begin{array}{c}\text { Estimated } \\
\text { coefficient }\end{array}$ \\
\hline Capra hircus & 356 & 356 & 1 \\
Ovis aries & 351 & 285 & 1.23 \\
& & 66 & 5.32 \\
Bos taurus & 350 & 223 & 1.57 \\
& & 127 & 2.75 \\
\hline
\end{tabular}


Table 3. Estimated data for determining the ratio of relative shares of the $\kappa$-casein gene in agricultural ruminant animals in mixed milk samples ${ }^{1}$

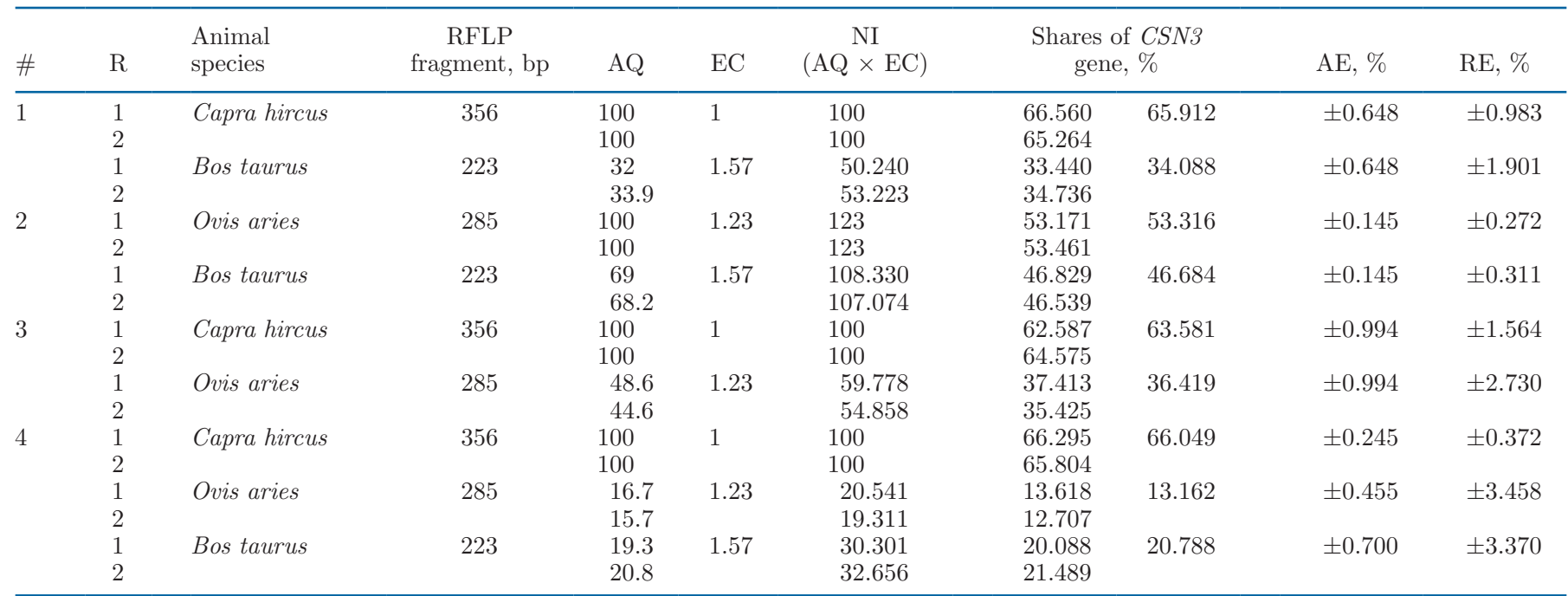

${ }^{1} \#=$ mixed milk samples numbers. $\mathrm{R}=$ repetition (2-fold) of the analyzed PCR-RFLP sample; AQ = value of the absolute quantity of the detected RFLP fragment, pre-calculated by the Image Lab software of the Bio-Rad Gel Doc XR+ gel documentation system. EC = estimated coefficient; $\mathrm{NI}(\mathrm{AQ} \times \mathrm{EC})=$ numerical indicator obtained by multiplying $\mathrm{AQ}$ and $\mathrm{EC} ; \mathrm{AE}=$ the absolute error of calculated proportion of $C S N 3$ gene of a certain type of agricultural ruminant animal, expressed in percentage; $\mathrm{RE}=$ relative error, expressed in percentage.

sis of several animal mitochondrial genes (Agrimonti and Marmiroli, 2018; Kalogianni, 2018).

In the course of this study, the developed and tested PCR-RFLP analysis technique, taking into account the potential and limitations of the method as such (Di Domenico et al., 2017; Guan et al., 2018; Hashim and Al-Shuhaib, 2019), provided species identification in milk and dairy products due to the effective interpretation of the generated PCR-RFLP profiles.

\section{CONCLUSIONS}

The developed PCR-RFLP analysis technique for the species identification of milk and dairy products from agricultural ruminant animals by the $\kappa$-casein gene provides a qualitative and relative quantitative assessment of species-specific DNA of the tested biomaterial with specialized software. The synergistic effect revealed during the combined operation of 2 restriction enzymes

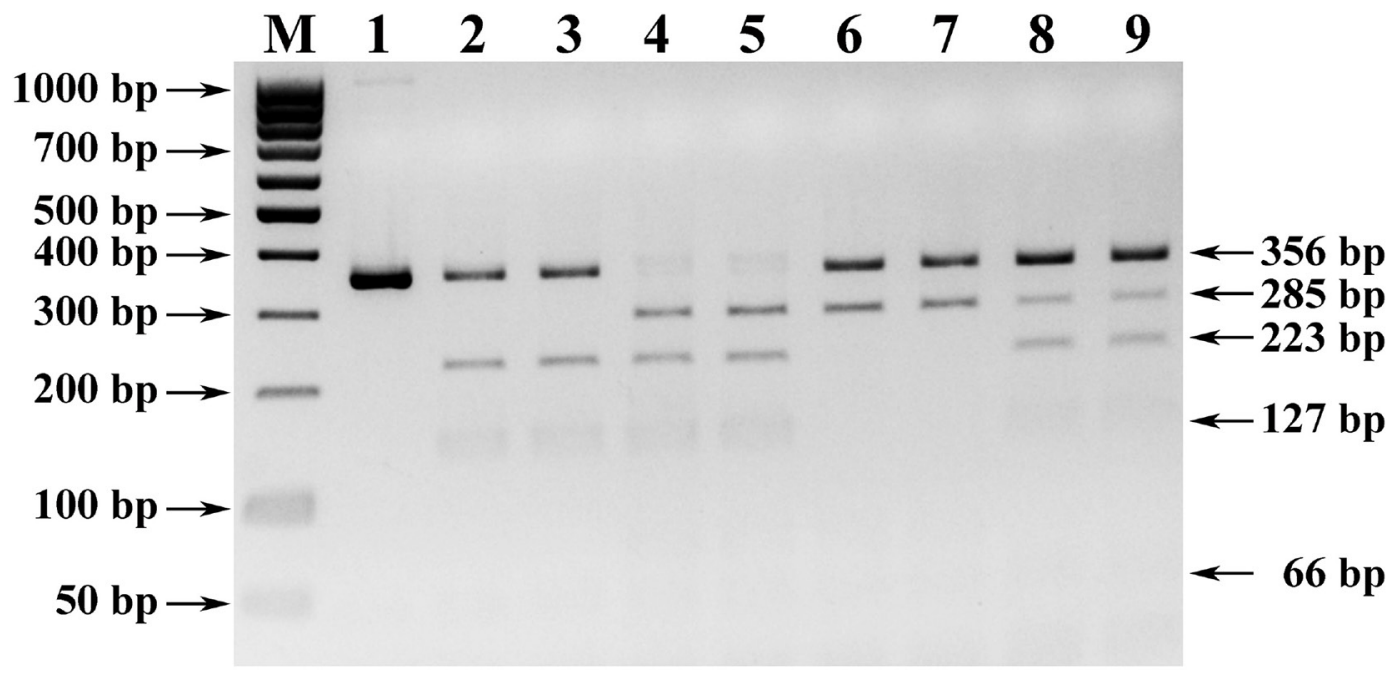

Figure 6. Electropherogram of the result of PCR-RFLP analysis of the species identification in mixed milk samples by the CSN3 gene. $\mathrm{M}=$ PCR marker (SibEnzyme); 1 = PCR product Bos taurus (350 bp); 2-9 = XbaI-PsiI-RFLP fragments: 2-3, Capra hircus + Bos taurus (356/223/127 bp); 4-5, Ovis aries + Bos taurus $(285 / 223 / 127 / 66$ bp);6-7, Capra hircus + Ovis aries (356/285/66 bp); 8-9, Capra hircus + Ovis aries + Bos taurus $(356 / 285 / 223 / 127 / 66$ bp $)$. 


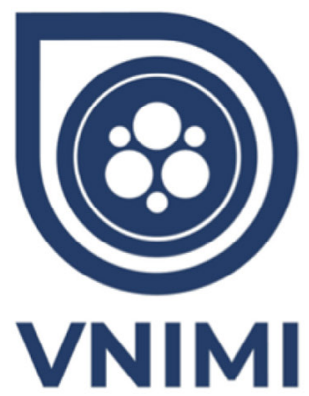

\section{Determining the ratio of relative shares of $\boldsymbol{x}$-casein}

of agricultural ruminant animals in tested samples of milk and dairy products

AQ \#

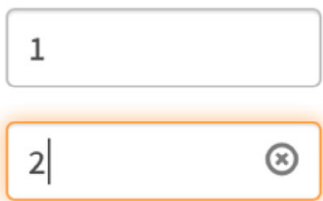

Capra hircus

100100

00
Ovis aries

$$
00
$$

100100
Bos taurus

3233.9

6968.2

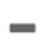

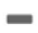

(a)

\begin{tabular}{|c|c|c|c|c|c|c|c|c|c|c|}
\hline$\#$ & $\mathbf{R}$ & Animal species & $\begin{array}{l}\text { RFLP-fragment, } \\
\text { bp }\end{array}$ & $\mathbf{A Q}$ & EC & NI & $\begin{array}{l}\text { Shares } \\
\text { gene, \% }\end{array}$ & of CSN3 & AE, $\%$ & RE, \% \\
\hline \multirow{3}{*}{1} & $\begin{array}{l}1 \\
2\end{array}$ & Capra hircus & $356 \mathrm{bp}$ & $\begin{array}{l}100 \\
100\end{array}$ & $\times 1$ & $\begin{array}{l}100 \\
100\end{array}$ & \begin{tabular}{|l|}
66.560 \\
65.264
\end{tabular} & 65.912 & \pm 0.648 & \pm 0.983 \\
\hline & \multicolumn{10}{|c|}{$\ldots$} \\
\hline & $\begin{array}{l}1 \\
2\end{array}$ & Bos taurus & $223 \mathrm{bp}$ & $\begin{array}{l}32 \\
33.9\end{array}$ & $\times 1.57$ & $\begin{array}{l}50.240 \\
53.223\end{array}$ & $\begin{array}{l}33.440 \\
34.736\end{array}$ & 34.088 & \pm 0.648 & \pm 1.901 \\
\hline \multirow{3}{*}{2} & \multicolumn{10}{|c|}{$\cdots$} \\
\hline & $\begin{array}{l}1 \\
2\end{array}$ & Ovis aries & $285 b p$ & $\begin{array}{l}100 \\
100\end{array}$ & $\times 1.23$ & $\begin{array}{l}123.000 \\
123.000\end{array}$ & \begin{tabular}{|l|}
53.171 \\
53.461
\end{tabular} & 53.316 & \pm 0.145 & \pm 0.272 \\
\hline & $\begin{array}{l}1 \\
2\end{array}$ & Bos taurus & $223 \mathrm{bp}$ & $\begin{array}{l}69 \\
68.2\end{array}$ & $\times 1.57$ & $\begin{array}{l}108.330 \\
107.074\end{array}$ & $\begin{array}{l}46.829 \\
46.539\end{array}$ & 46.684 & \pm 0.145 & \pm 0.311 \\
\hline
\end{tabular}

(b)

Figure 7. (a) Interface of the developed program "Determining the ratio of relative shares of k-casein of agricultural ruminant animals in tested samples of milk and dairy products." User is able to add any number of samples and input absolute quantities (AQ) of the detected RFLP fragment for each ruminant and each test repetition. (b) Program output with columns identical to the columns of Table 3. $\mathrm{R}=$ repetition $(2-$ fold) of the analyzed PCR-RFLP sample, AQ = value of the absolute quantity of the detected RFLP fragment, pre-calculated by the Image Lab software of the Bio-Rad Gel Doc XR + gel documentation system. EC = estimated coefficient; NI $(\mathrm{AQ} \times \mathrm{EC})=$ numerical indicator obtained by multiplying $\mathrm{AQ}$ and $\mathrm{EC} ; \mathrm{AE}=$ the absolute error of calculated proportion of the CSN3 gene of a certain type of agricultural ruminant animal, expressed in percentage; $\mathrm{RE}=$ relative error, expressed in percentage. 


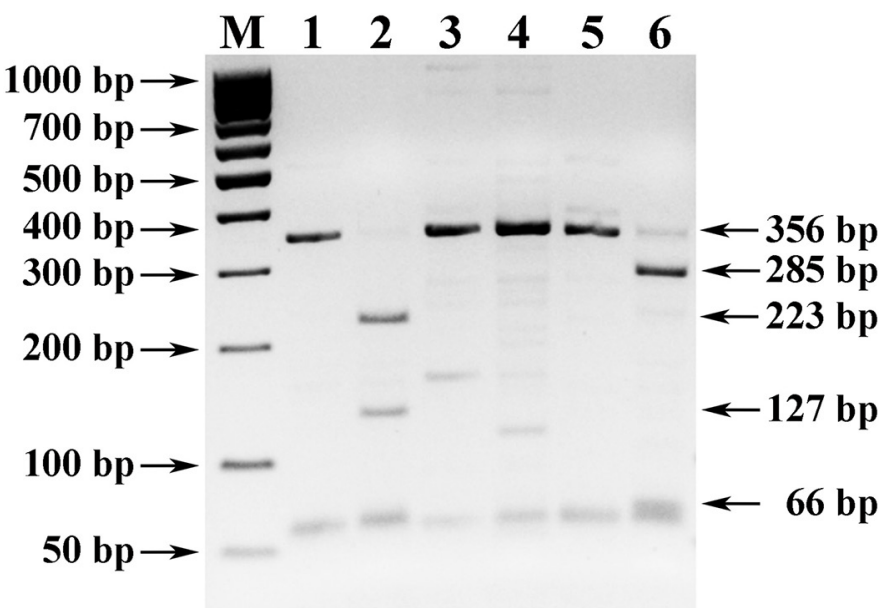

Figure 8. Electropherogram of the result of PCR-RFLP analysis of the species identification of cheeses by the CSN3 gene. $\mathrm{M}=$ PCR marker (SibEnzyme). 1-2 = Cow cheese: 1, PCR product $(350$ bp); 2, XbaI-PsiI-RFLP fragment $(223 / 127 \mathrm{bp}) .3-4=$ Goat cheese: 3, PCR product (356 bp); 4, XbaI-PsiI-RFLP fragment (356 bp). 5-6 $=$ Sheep cheese: 5 , PCR product $(351 \mathrm{bp}) ; 6=X b a \mathrm{I}-P$ siI-RFLP fragment (285/66 bp).

$(X b a \mathrm{I}+$ PsiI $)$ ensured their application in a mix with increased performance and ergonomics of the procedure for DNA authentication of cow, goat, and sheep milk and dairy products based on them. Interpretation of the results of PCR-RFLP analysis technique is appropriate for identification of significant major RFLP fragments generated during endonuclease cleavage of PCR products amplified with a selected thermal cycling mode depending on the type of sample under study. Specificity and sensitivity of the developed technique is potentially suitable for implementing the development of a system for controlling the turnover of falsified or counterfeit goods.

\section{ACKNOWLEDGMENTS}

This research was not conducted under any specific grant or external source of funding. The authors have not stated any conflicts of interest.

\section{REFERENCES}

Abbas, O., M. Zadravec, V. Baeten, T. Mikuš, T. Lešić, A. Vulić, J. Prpic, L. Jemeršić, and J. Pleadin. 2018. Analytical methods used for the authentication of food of animal origin. Food Chem. 246:6-17. https://doi.org/10.1016/j.foodchem.2017.11.007.

Abdel-Rahman, S. M., and M. M. M. Ahmed. 2007. Rapid and sensitive identification of buffalo's, cattle's and sheep's milk using species-specific PCR and PCR-RFLP techniques. Food Control 18:1246-1249. https://doi.org/10.1016/j.foodcont.2006.08.003.

Abdelfatah, E. N., I. E. El-Araby, and A. A. Mohamed. 2015. Identification of species adulteration in raw milk and butter using poly- merase chain reaction-restriction fragment length polymorphism. Glob. Vet. 15:332-338. https://doi.org/10.5829/idosi.gv.2015.15 .03.10128.

Agrimonti, C., B. Bottari, M. L. S. Sardaro, and N. Marmiroli. 2019. Application of real-time PCR (qPCR) for characterization of microbial populations and type of milk in dairy food products. Crit. Rev. Food Sci. Nutr. 59:423-442. https://doi.org/10.1080/ 10408398.2017.1375893.

Agrimonti, C., and N. Marmiroli. 2018. Genomics for detecting adulteration in dairy food chain. Frontiers in Drug Safety 1:13-36. https://doi.org/10.2174/9781681086750118010005.

Beltramo, C., M. V. Riina, S. Colussi, V. Campia, M. G. Maniaci, C. Biolatti, S. Trisorio, P. Modesto, S. Peletto, and P. L. Acutis. 2017. Validation of a DNA biochip for species identification in food forensic science. Food Control 78:366-373. https://doi.org/10 .1016/j.foodcont.2017.03.006.

Böhme, K., P. Calo-Mata, J. Barros-Velázquez, and I. Ortea. 2019a. Recent applications of omics-based technologies to main topics in food authentication. Trends Analyt. Chem. 110:221-232. https:// doi.org/10.1016/j.trac.2018.11.005.

Böhme, K., P. Calo-Mata, J. Barros-Velázquez, and I. Ortea. 2019b. Review of recent DNA-based methods for main food-authentication topics. J. Agric. Food Chem. 67:3854-3864. https://doi.org/ 10.1021/acs.jafc.8b07016.

Bougadi, E. T., and D. P. Kalogianni. 2020. Paper-based DNA biosensor for food authenticity testing. Food Chem. 322:126758. https:// doi.org/10.1016/j.foodchem.2020.126758.

Choopan, R., P. Thanakiatkrai, and T. Kitpipit. 2017. Simultaneous species identification in milk and dairy products using direct PCR. Forensic Sci. International. Genet. Suppl. Ser. 6:e214-e215. https: //doi.org/10.1016/j.fsigss.2017.09.077.

Cosenza, G., M. Iannaccone, D. Gallo, and A. Pauciullo. 2019. A fast and re-liable polymerase chain reaction method based on short interspersed nuclear elements detection for the discrimination of buffalo, cattle, goat, and sheep species in dairy products. AsianAustralas. J. Anim. Sci. 32:891-895. https://doi.org/10.5713/ajas .18 .0459

Creydt, M., and M. Fischer. 2020. Food authentication in real life: How to link nontargeted approaches with routine analytics? Electrophoresis 41:1665-1679. https://doi.org/10.1002/elps.202000030.

Deng, L., A. Li, Y. Gao, T. Shen, H. Yue, J. Miao, R. Li, and J. Yang. 2020. Detection of the bovine milk adulterated in camel, horse, and goat milk using duplex PCR. Food Anal. Methods 13:560-567. https://doi.org/10.1007/s12161-019-01678-2.

Di Domenico, M., M. Di Giuseppe, J. W. Rodríguez, and C. Cammà 2017. Validation of a fast real-time PCR method to detect fraud and mislabeling in milk and dairy products. J. Dairy Sci. 100:106112. https://doi.org/10.3168/jds.2016-11695.

Di Febo, T., M. Schirone, M. Di Domenico, P. Visciano, I. Krasteva, L. Sonsini, O. Cerquaglia, S. Carpino, F. D'Onofrio, M. Tittarelli, and M. Luciani. 2020. Detection of undeclared bovine milk in different food matrices by a multi-technique approach. Int. Dairy J. 111:104845. https://doi.org/10.1016/j.idairyj.2020.104845.

El Sheikha, A. F. 2019. DNAFoil: Novel technology for the rapid detection of food adulteration. Trends Food Sci. Technol. 86:544-552. https://doi.org/10.1016/j.tifs.2018.11.012.

Ewida, R. M., and D. S. M. Abd El-Magiud. 2018. Species adulteration in raw milk samples using polymerase chain reaction-restriction fragment length polymorphism. Vet. World 11:830. https:// doi.org/10.14202/vetworld.2018.830-833.

Guan, F., Y. T. Jin, J. Zhao, A. C. Xu, and Y. Y. Luo. 2018. A PCR method that can be further developed into PCR-RFLP assay for eight animal species identification. J. Anal. Methods Chem. https: //doi.org/10.1155/2018/5890140.

Habza-Kowalska, E., M. Grela, M. Gryzinska, and P. Listos. 2019 Molecular techniques for detecting food adulteration. Med. Weter. 75:404-409. https://doi.org/10.21521/mw.626.

Hashim, H. O., and M. B. S. Al-Shuhaib. 2019. Exploring the potential and limitations of PCR-RFLP and PCR-SSCP for SNP detection: A review. J. Appl. Biotechnol. Rep. 6:137-144. https://doi.org/10 .29252/JABR.06.04.02. 
Kalogianni, D. P. 2018. DNA-based analytical methods for milk authentication. Eur. Food Res. Technol. 244:775-793. https://doi .org/10.1007/s00217-017-3016-x.

Kang, T. S. 2019. Basic principles for developing real-time PCR methods used in food analysis: A review. Trends Food Sci. Technol. 91:574-585. https://doi.org/10.1016/j.tifs.2019.07.037.

Kounelli, M. L., and D. P. Kalogianni. 2017. A sensitive DNA-based fluorometric method for milk authenticity of dairy products based on spectrally distinct microspheres. Eur. Food Res. Technol. 243:1773-1781. https://doi.org/10.1007/s00217-017-2882-6.

Levin, R. E., F. G. C. Ekezie, and D. W. Sun. 2018. DNA-based technique: Polymerase chain reaction (PCR). Pages 527-616 in Modern Techniques for Food Authentication. Academic Press. https:// doi.org/10.1016/B978-0-12-814264-6.00014-1.

Liao, J., Y. F. Liu, T. Ku, M. H. Liu, and Y. Huang. 2017b. Qualitative and quantitative identification of adulteration of milk powder using DNA extracted with a novel method. J. Dairy Sci. 100:16571663. https://doi.org/10.3168/jds.2016-11900.

Liao, J., Y. F. Liu, L. Yang, F. P. Li, and A. M. Sheppard. 2017a. Development of a rapid mitochondrial DNA extraction method for species identification in milk and milk products. J. Dairy Sci. 100:7035-7040. https://doi.org/10.3168/jds.2017-12653.

Liu, Y. F., J. L. Gao, Y. F. Yang, T. Ku, and L. S. Zan. 2014. Novel extraction method of genomic DNA suitable for long-fragment amplification from small amounts of milk. J. Dairy Sci. 97:6804-6809. https://doi.org/10.3168/jds.2014-8066.

Lo, Y. T., and P. C. Shaw. 2018. DNA-based techniques for authentication of processed food and food supplements. Food Chem. 240:767-774. https://doi.org/10.1016/j.foodchem.2017.08.022.

Medrano, J. F., and E. A. Cordova. 1990. Genotyping of bovine kappacasein loci following DNA sequence amplification. Biotechnology (NY) 8:144-146. https://doi.org/10.1038/nbt0290-144.

Oganesyants, L. A., R. R. Vafin, A. G. Galstyan, V. K. Semipyatniy, S. A. Khurshudyan, and A. E. Ryabova. 2018. Prospects for DNA authentication in wine production monitoring. Foods and Raw Materials 6:438-448. https://doi.org/10.21603/2308-4057-2018-2 $-438-448$

Otaviano, A. R., A. L. F. Lima, M. M. Laureano, J. A. Sena, L. G. D. Albuquerque, and H. Tonhati. 2008. $\beta$-casein gene polymorphism permits identification of bovine milk mixed with bubaline milk in mozzarella cheese. Genet. Mol. Biol. 31:902-905. https://doi.org/ 10.1590/S1415-47572008005000002

Poonia, A., A. Jha, R. Sharma, H. B. Singh, A. K. Rai, and N. Sharma. 2017. Detection of adulteration in milk: A review. Int. J. Dairy Technol. 70:23-42. https://doi.org/10.1111/1471-0307.12274.

Reale, S., A. Campanella, A. Merigioli, and F. Pilla. 2008. A novel method for species identification in milk and milk-based products. J. Dairy Res. 75:107-112. https://doi.org/10.1017/ s0022029907003020.

Ribani, A., G. Schiavo, V. J. Utzeri, F. Bertolini, C. Geraci, S. Bovo, and L. Fontanesi. 2018. Application of next generation semiconductor based sequencing for species identification in dairy products. Food Chem. 246:90-98. https://doi.org/10.1016/j.foodchem 2017.11.006.

Ripp, F., C. F. Krombholz, Y. Liu, M. Weber, A. Schäfer, B. Schmidt, R. Köppel, and T. Hankeln. 2014. All-Food-Seq (AFS): A quantifiable screen for species in biological samples by deep DNA sequencing. BMC Genomics 15:639. https://doi.org/10.1186/1471-2164-15 -639 .

Tillmar, A. O., B. Dell'Amico, J. Welander, and G. Holmlund. 2013. A universal method for species identification of mammals utilizing next generation sequencing for the analysis of DNA mixtures. PLoS One 8:e83761. https://doi.org/10.1371/journal.pone.0083761.

Tsakali, E., C. Agkastra, C. Koliaki, D. Livanios, G. Boutris, M. I. Christopoulou, S. Koulouris, S. Koussissis, J. F. Van Impe, and D. Houhoula. 2019. Milk adulteration: Detection of bovine milk in caprine dairy products by real time PCR. J. Food Res. 8:52-57. https://doi.org/10.5539/jfr.v8n4p52.

Tsirigoti, E., Z. Katsirma, A. I. Papadopoulos, G. Samouris, L. V. Ekateriniadou, and E. Boukouvala. 2020. Application of triplexPCR with an innovative combination of 3 pairs of primers for the detection of milk's animal origin in cheese and yoghurt. J. Dairy Res. 87:239-242. https://doi.org/10.1017/S0022029920000242.

Tyulkin, S. V. 2018. The effect of cows genotype on their productivity and milk quality. Food Systems 1:38-43. https://doi.org/10 .21323/2618-9771-2018-1-3-38-43.

Xu, W. L., and Y. Ma. 2012. Comparison of different extraction methods of genomic DNA from milk powder. Journal of Harbin Institute of Technology 8.

\section{ORCIDS}

R. R. Vafin @ https://orcid.org/0000-0003-0914-0053

A. G. Galstyan @ https://orcid.org/0000-0002-0786-2055

S. V. Tyulkin (ํ) https://orcid.org/0000-0001-5379-237X

Kh. Kh. Gilmanov ๑ https://orcid.org/0000-0001-7053-6925

E. A. Yurova @ https://orcid.org/0000-0003-3369-5673

V. K. Semipyatniy @ https://orcid.org/0000-0003-1241-0026

A. V. Bigaeva ๑ https://orcid.org/0000-0001-8400-2465 